\title{
Molecular detection of Leishmania infantum DNA according to clinical stages of leishmaniasis in dog
}

\section{Deteção molecular de DNA de Leishmania infantum em diferentes estágios clínicos da leishmaniose em cães}

Murilo Antônio Fernandes ${ }^{1,2}$; João Augusto Franco Leonel ${ }^{1,2}$; Jéssica Anzolin Isaac'; Julia Cristina Benassi ${ }^{1}$;

Diogo Tiago Silva ${ }^{1,2}$; Julio Cesar Pereira Spada ${ }^{1,2}$; Nuno Wolfgang Balbini Pereira ${ }^{1,2}$; Helena Lage Ferreira ${ }^{1,2}$;

Lara Borges Keid ${ }^{1,2}$; Rodrigo Martins Soares ${ }^{2,3}$; Trícia Maria Ferreira de Sousa Oliveira ${ }^{1,2 *}$ (1)

\begin{abstract}
${ }^{1}$ Laboratório de Medicina Veterinária Preventiva Aplicada, Departamento de Medicina Veterinária, Faculdade de Zootecnia e Engenharia de Alimentos, Universidade de São Paulo - USP, Pirassununga, SP, Brasil

${ }^{2}$ Programa de Pós-graduação em Epidemiologia Experimental Aplicada às Zoonoses, Departamento de Medicina Veterinária Preventiva, Faculdade de Medicina Veterinária e Zootecnia, Universidade de São Paulo - USP, São Paulo, SP, Brasil

${ }^{3}$ Laboratório de Doenças Parasitárias, Departamento de Medicina Veterinária Preventiva, Faculdade de Medicina Veterinária e Zootecnia, Universidade de São Paulo - USP, Pirassununga, SP, Brasil
\end{abstract}

Received October 8, 2018

Accepted February 19, 2019

\begin{abstract}
The aim of this study was to compare molecular tests used to diagnose Leishmania spp. in dogs with different stages of infection. Blood and conjunctival swab (CS) samples from dogs classified in four clinical stages were subjected to different PCR protocols (13A/13B, MC1/MC2, LITSR/L5.8S and LEISH-1/LEISH-2 primers). To the study, $22.3 \%$ (48/215) of dogs were classified as without clinical signs, $67.5 \%$ (145/215) stage I (mild disease), 7.0\% (15/215) stage II (moderate disease) and 3.2\% (7/215) stage III (severe disease). The results showed that in blood samples, 13A/13B detected a significant higher number of positive dogs in stage I $(25 / 145)$ and in total $(42 / 215)(\mathrm{p} \leq 0.05)$. However, when CS samples were tested, no difference was observed ( $\mathrm{p}>0.05$ ). On the other hand, in blood samples, MC1/MC2 detected significantly fewer positive dogs classified as without clinical signs (0/48), in stage I (0/145) and in total $(1 / 215)(\mathrm{p} \leq 0.05)$. Likewise, in CS samples, this primers showed also lower detection $(1 / 215)(\mathrm{p} \leq 0.05)$. So than, we can conclude that PCR on blood samples with $13 \mathrm{~A} / 13 \mathrm{~B}$ primers has greater capacity to detect positive dogs, mainly at the initial of clinical disease than do other primers and MC1/MC2 are not a good choice to detect Leishmania infantum infection in dogs.
\end{abstract}

Keywords: Canine visceral leishmaniasis, dog, Leishmania spp., PCR, stages of disease.

\section{Resumo}

O objetivo deste estudo foi comparar testes moleculares usados para diagnosticar Leishmania spp., em cães apresentando diferentes estágios de infecçấo. Amostras de sangue e suabe conjuntival (SC) de cáes classificados em quatro estágios clínicos foram submetidas a diferentes PCRs (primers 13A/13B, MC1/MC2, LITSR/L5.8S e LEISH-1/LEISH-2). Para o estudo, 22,3\% (48/215) dos cães foram classificados como sem sinais clínicos, 67,5\% (145/215) estágio I (doença leve), 7,0\% (15/215) estágio II (doença moderada) e 3,2\% (7/215) estágio III (doença grave). Os resultados mostraram que, em amostras de sangue, 13A/13B detectou número significativamente maior de cães positivos no estágio I (25/145) e no total $(42 / 215)(p \leq 0,05)$. No entanto, quando as amostras de $S C$ foram testadas, nenhuma diferença foi observada $(\mathrm{p}>0,05)$. Por outro lado, no sangue, $\mathrm{MC1} / \mathrm{MC} 2$ detectou significativamente menos cães positivos sem sinais clínicos $(0 / 48)$, em estágio I $(0 / 145)$ e no total $(1 / 215)$ ( $\mathrm{p} \leq 0,05)$. Da mesma forma, em amostras de SC, MC1/MC2 também apresentou menor deteç̧ão $(1 / 215)(\mathrm{p} \leq 0,05)$. Assim, a PCR em amostras de sangue com 13A/13B tem maior capacidade de detectar cáes positivos, principalmente no início da doença do que outros primers, e o par de primers MC1/MC2 não é uma boa escolha para detectar infecção por Leishmania infantum em cães.

Palavras-chave: Leishmaniose visceral canina, cão, Leishmania spp., PCR, estágios da doença.

*Corresponding author: Trícia Maria Ferreira de Sousa Oliveira.

Departamento de Medicina Veterinária, Faculdade de Zootecnia e Engenharia

de Alimentos, Universidade de Sáo Paulo - USP, Avenida Duque de Caxias

Norte, 225, CEP 13635-900, Pirassununga, SP, Brasil. e-mail: tricia@usp.br 


\section{Introduction}

The leishmaniases are a group of zoonotic infectious diseases that affect humans and domestic and wild animals. They are caused by protozoa of the genus Leishmania (DESJEUX, 2004; WHO, 2016). Today, they are considered to be among the six most important types of infectious and parasitic diseases in the world (LANGONI et al., 2015). One hundred and two countries in East and Southeast Asia, the Middle East, North and East Africa, Southern Europe (Mediterranean) and Central and South America are considered endemic for leishmaniases (ALVAR et al., 2012; WHO, 2016). In these countries, it has been estimated that approximately 0.2 to 0.4 million new cases of visceral leishmaniasis (VL) and 0.7 to 1.2 million new cases of cutaneous leishmaniasis (CL) occur every year (WHO, 2016). These cases form a challenge for public health (LOPES et al., 2016).

The leishmaniases has been described in several domestic and wild animals, including in carnivores, didelphimorphs, rodents, equids and primates (ASHFORD, 1996; DUARTE et al., 2010; SOARES et al., 2013; BENASSI et al., 2017). In domestic environments, dogs are considered to be the main epidemiological reservoir, with great importance for maintenance of the zoonotic VL cycle (QUINNELL \& COURTENAY, 2009; MAIA \& CAMPINO 2011). The concern regarding canine visceral leishmaniasis (CVL) is that it is more prevalent than is VL in humans. Great numbers of parasites are harbored in the skin of dogs, which favors vector infection (ARIAS et al., 1996).

Despite the importance of making accurate diagnoses among infected dogs for effective disease control, this remains a challenge (FERREIRA et al., 2014). Currently, immunoenzymatic (ELISA) and immunochromatographic (Dual Path Platform, Bio-Manguinhos ${ }^{\circledR}$ ) serological tests are recommended for diagnosing Leishmania spp. infection in dogs from Brazil (BRASIL, 2011). However, serological tests have limitations such as low diagnostic sensitivity in dogs without clinical sings and cross-reactions with other trypanosomatids (TRONCARELLI et al., 2009; GRIMALDI et al., 2012). As an alternative to indirect tests, molecular methods play an important role in confirmation of diagnoses, identification of causative Leishmania spp. and detection of carriers (GRAMICCIA, 2011).

The polymerase chain reaction (PCR) is the molecular method most used in these studies, and it enables selective amplification of target sequences in the parasite's DNA (DEGRAVE et al., 1994). The technique has been shown to be an important tool for detecting and diagnosing Leishmania spp. infection (MAIA \& CAMPINO, 2008; ASSIS et al., 2010; COURA-VITAL et al., 2011; SOLANO-GALLEGO et al., 2011; MOHAMMADIHA et al., 2013). Several molecular techniques, biological samples and target genes are used in detecting Leishmania spp. DNA (MAIA \& CAMPINO, 2008). However, the results obtained by several research groups are quite different. Thus, PCR use is far from having been standardized for Leishmania spp. infection (LACHAUD et al., 2002). In Brazil, there is no consensus among researchers regarding the primers that would be best for making the diagnosis of Leishmania spp. infection (LOPES et al., 2016). According to Courtenay et al. (2002) there is a positive correlation between parasite DNA detection by PCR and clinical disease. Thus, with the aim to elucidated differences among molecular tests used to diagnose Leishmania spp., related to different clinical phases of infection, this study was performed.

\section{Materials and Methods}

\section{Study area}

This study was carried out on the canine population of four cities in the state of São Paulo, Brazil. In this state, 10,934 cases of cutaneous leishmaniasis (CL) and 2,546 cases of visceral leishmaniasis (VL) were registered over the last 26 years (BRASIL, 2018a, b). The cities of Pirassununga ( $21^{\circ} 59^{\prime} 46^{\prime \prime} \mathrm{S}$ and $\left.47^{\circ} 25^{\prime} 33^{\prime \prime} \mathrm{W}\right)$ and Santa Cruz das Palmeiras ( $21^{\circ} 48^{\prime} 49^{\prime \prime} \mathrm{S}$ and $\left.47^{\circ} 15^{\prime} 23^{\prime \prime} \mathrm{W}\right)$ are areas where CL is endemic with 117 and 6 human cases, respectively, registered over the last 17 years, but no VL cases were registered (BRASIL, 2018c, d, e, f). On the other hand,

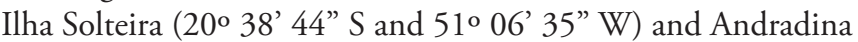
(20'53'46" S and 51'22' 46" W) are endemic regions for both CL and VL. Between 2001 and 2017, 3 and 18 human CL cases were registered in Ilha Solteira and Andradina, respectively (BRASIL, 2018c, d) and 12 and 98 cases of human VL were registered in the same cities (BRASIL, 2018e, f).

\section{Samples}

Between 2014 and 2015, biological samples were collected from 215 dogs. All the animals came from municipal kennels or from animal protection shelters belonging to animal protection organizations. Blood samples were collected directly from the cephalic or external jugular veins. Samples were collected in tubes containing EDTA (at a proportion of $1 \mathrm{mg} / \mathrm{mL}$ ) for hemograms and DNA analysis, and in tubes with no anticoagulant for serological and biochemical tests. Hemograms and biochemical tests were done on the same day after sampling. Blood and serum samples were stored at $-20{ }^{\circ} \mathrm{C}$ until serological analysis and DNA extraction. Exfoliative epithelial cells were collected from both eyes using sterile swabs manufactured for bacteriological isolation. The conjunctival swab samples were stored at $4{ }^{\circ} \mathrm{C}$ until DNA extraction.

This study was approved by the Ethics Committee for Animal Use, under registration number 7839110215.

\section{Animal ranking}

The clinical signs observed and the quantitative results from the biochemical and serological tests were used to rank the animals into four clinical stages: without clinical signs, mild disease (I), moderate disease (II) and severe disease (III), in accordance with an adaptation of the disease classification of Solano-Gallego et al. (2011), as described in Table 1.

\section{Clinical examinations}

At the time of the sample collection, the dogs were also subjected to clinical examinations. Thus, each animal was carefully examined regarding mucosal color, nutritional status, abdominal 
Table 1. Clinical classification of dogs based on serology, clinical signs and laboratory findings.

\begin{tabular}{|c|c|c|c|}
\hline Clinical stages & Serology & Clinical signs & Laboratory findings \\
\hline Without clinical signs & Negative & Absent & No clinicopathological abnormalities \\
\hline $\begin{array}{l}\text { Stage I } \\
\text { Mild disease }\end{array}$ & $\begin{array}{l}\text { Negative to low positive antibody } \\
\text { levels } \\
\text { EL: } 0-3^{*}\end{array}$ & $\begin{array}{l}\text { Dogs with moderate clinical signs such as } \\
\text { peripheral lymph adenomegaly or papular } \\
\text { dermatitis }\end{array}$ & $\begin{array}{l}\text { Usually without observed clinical and } \\
\text { pathological abnormalities } \\
\text { Creatinine }<1,4 \mathrm{mg} / \mathrm{dl}\end{array}$ \\
\hline $\begin{array}{l}\text { Stage II } \\
\text { Moderate disease }\end{array}$ & $\begin{array}{l}\text { Low to medium positive } \\
\text { antibody levels } \\
\text { EL: } 4-5^{*}\end{array}$ & $\begin{array}{l}\text { Dogs, which apart from the signs listed in } \\
\text { stage I, may present: diffuse or symmetrical } \\
\text { cutaneous lesions such as exfoliative } \\
\text { dermatitis/onychogryphosis, ulcerations, } \\
\text { anorexia, weight loss, fever, and epistaxis }\end{array}$ & $\begin{array}{l}\text { Clinicopathological abnormalities } \\
\text { such as mild non-regenerative } \\
\text { anemia, hyperglobulinemia, } \\
\text { hypoalbuminemia, serum } \\
\text { hyperviscosity syndrome } \\
\text { Creatinine }<1,4 \mathrm{mg} / \mathrm{dl}\end{array}$ \\
\hline $\begin{array}{l}\text { Stage III } \\
\text { Severe disease }\end{array}$ & $\begin{array}{l}\text { Medium to high positive } \\
\text { antibody levels } \\
\text { EL: } 6-9^{*}\end{array}$ & $\begin{array}{l}\text { Dogs, in addition to the signs listed in stages } \\
\text { I and II, may show signs originating from } \\
\text { lesions of the immune complex: vasculitis, } \\
\text { arthritis, uveitis, and glomerulonephritis. } \\
\text { At very severe cases: pulmonary } \\
\text { thromboembolism or nephrotic syndrome }\end{array}$ & $\begin{array}{l}\text { Clinicopathological abnormalities } \\
\text { listed in stage II } \\
\text { Creatinine }>1,5 \mathrm{mg} / \mathrm{dl}\end{array}$ \\
\hline
\end{tabular}

${ }^{*} \mathrm{EL}=$ ELISA level.

and lymph node alterations (lymphadenopathy) and ocular and dermatological alterations: alopecia, dermatitis, onychogryphosis and conjunctivitis. All signs observed were recorded on an individual clinical sheet for each dog.

\section{Hematological tests}

Hemograms were performed using automated equipment (BC-2800Vet ${ }^{\circledR}$; Mindray) to obtain total counts of leukocytes, red blood cells, hemoglobin, hematocrit and platelets. Differential leukocyte counts and cell morphology evaluations were performed using Rosenfeld-stained blood smears. The hepatic and renal function of these dogs was assessed through measurements of alanine aminotransferase (ALT/GPT Liquiform Vet ${ }^{\circledR}$; LabTest, ref. 1008-4/30), aspartate aminotransferase (AST/GOT Liquiform ${ }^{\circledR}$; LabTest, ref. 109-4/30), urea (UREA UV Liquiform ${ }^{\circledR}$; LabTest, ref. 104-4/50) and creatinine (CREATININA $\mathrm{K}^{\circledR}$; LabTest, ref. 96-300), using a BS-120 ${ }^{\circledR}$ (Mindray) calibrated through Calibra $\mathrm{H}^{\circledR}$ (LabTest, ref. 80) and quality control through Qualitrol $1 \mathrm{H}^{\circledR}$ (LabTest, ref. 71).

\section{Serological tests}

The serological evaluation on the levels of antibodies for Leishmania spp. was performed by means of the enzyme-linked immunosorbent assay (indirect ELISA), in accordance with Oliveira et al. (2008) in an EL $800^{\circledR}$ universal microplate reader (BioTek Instruments).

\section{DNA extraction}

DNA extraction from blood samples was performed using the DNeasy ${ }^{\circledR}$ Blood \& Tissue kit (Qiagen), in accordance with the manufacturer's recommendations. DNA extraction from conjunctival swab samples was performed using the salting-out technique described by John et al. (1991), as modified by Lahiri \& Numberger (1991). At final DNA extraction protocol, the conjunctival swabs from each eye were mixed and, thus, for this reason, the two conjunctival swabs from each dog were considered to be a single sample. The DNA samples were quantified in a DS- $11^{\circledR}$ spectrophotometer (DeNovix). The DNA extracted was stored at $-20{ }^{\circ} \mathrm{C}$ until analysis.

\section{Conventional PCR (cPCR)}

PCR amplification for the genus Leishmania was performed as described by Rodgers et al. (1990) and El Tai et al. (2000) and, for the species Leishmania infantum, we used the methodology of Cortes et al. (2004) (Table 2). All amplification was performed in a thermocycler Veriti ${ }^{\circledR}$ (Applied Biosystems). Sterile deionized water was used as a negative control. DNA samples extracted from Leishmania amazonensis (IFLA/BR/1967/ph8) and L. infantum (MCAN/BR/1984/CCC-17.481), which were provided by the Leishmaniasis Laboratory of the Oswaldo Cruz Institute (FIOCRUZ), Rio de Janeiro, were used as a positive control. Twelve microliters of PCR products were mixed with $3 \mu \mathrm{L}$ of sample buffer $(10 \mathrm{mM}$ Tris, $10 \mathrm{mM}$ EDTA, $0.005 \% \mathrm{~m} / \mathrm{v}$ bromophenol blue and 10\% v/v glycerol) and subjected to electrophoresis on $1.5 \%$ agarose gel (EL TAI et al. 2000) and 2\% agarose gel (CORTES et al., 2004; RODGERS et al., 1990) stained with SYBR ${ }^{\circledR}$ Safe (Invitrogen). The run was performed in $1 \times$ TBE buffer at $100 \mathrm{~V}$ (volts) for 60 min with DNA MW Marker 100-bp Ladder ${ }^{\circledR}$ (Amresco). A UV Photo Doc-It ${ }^{\circledR}$ (UVP) transilluminator was used to view the amplified products.

\section{Quantitative PCR (qPCR)}

To exclude false negatives stemming from PCR errors or sample degradation, a real-time PCR for the endogenous $\beta$-actin gene was performed as described by Manna et al. (2006) (Table 2). 
Table 2. Name, target gene, nucleotide sequence and the references of the primers and probe used to the study.

\begin{tabular}{|c|c|c|c|c|c|}
\hline PRC Target & Primer & PCR Concentration & $\begin{array}{l}\text { PCR Thermal } \\
\text { Condition }\end{array}$ & Size & Reference \\
\hline $\begin{array}{l}\mathrm{kDNA} \\
\text { Leishmania spp. }\end{array}$ & $\begin{array}{l}\text { 13A (5'-GTGGGGGAGGGGCGTTCT-3') } \\
\text { 13B (5'-ATTTTACACCAACCCCCAGTT-3') }\end{array}$ & $\begin{array}{l}\text { 200mM Tris- } \mathrm{HCl} ; \\
500 \mathrm{mM} \mathrm{KCl} ; 1,5 \mathrm{mM} \\
\mathrm{MgCl} 2 ; 0,31 \mathrm{mM} \\
\text { DNTP's; } 0,26 \mu \mathrm{M} \text { primer; } \\
\text { 1U Taq Polimerase }\end{array}$ & $\begin{array}{l}94^{\circ} \mathrm{C} 3 \mathrm{~min}, 35 \\
\text { cycles }\left(94^{\circ} \mathrm{C} 40 \mathrm{~s},\right. \\
56^{\circ} \mathrm{C} 30 \mathrm{~s}, 72^{\circ} \mathrm{C} \\
30 \mathrm{~s}), 72^{\circ} \mathrm{C} 5 \mathrm{~min}\end{array}$ & $120 \mathrm{bp}$ & $\begin{array}{l}\text { Rodgers et al. } \\
(1990)\end{array}$ \\
\hline \multirow[t]{2}{*}{$\begin{array}{l}\mathrm{kDNA} \\
\text { Leishmania } \\
\text { infantum }\end{array}$} & $\begin{array}{l}\text { MC1 (5'-GTTAGCCGATGGTG- } \\
\text { GTCTTG-3') } \\
\text { MC2 (5'-CACCCATTTTTCCGATTT TG-3') }\end{array}$ & $\begin{array}{l}\text { 200mM Tris- } \mathrm{HCl} \\
500 \mathrm{mM} \mathrm{KCl} ; 1,5 \mathrm{mM} \\
\mathrm{MgCl} 2 ; 10 \mathrm{mM} \text { DNTP's; } \\
50 \mathrm{pmol} \text { primer; } 1,25 \mathrm{U} \\
\text { Taq Polimerase }\end{array}$ & $\begin{array}{l}94^{\circ} \mathrm{C} 2 \mathrm{~min}, 30 \\
\text { cycles }\left(94^{\circ} \mathrm{C} 20 \mathrm{~s}\right. \\
60^{\circ} \mathrm{C} 20 \mathrm{~s}, 72^{\circ} \mathrm{C} \\
30 \mathrm{~s}), 72^{\circ} \mathrm{C} 5 \mathrm{~min}\end{array}$ & $447 b p$ & $\begin{array}{l}\text { Cortes et al. } \\
(2004)\end{array}$ \\
\hline & $\begin{array}{l}\text { LEISH-1 (5'-AACTTTTCTGGTCCTCC- } \\
\text { GGGTAG-3') } \\
\text { LEISH-2 (5'-ACCCCCAGTTTCCCGCC-3') } \\
\text { TaqMan probe (5'-AACTTTTCTG- } \\
\text { GTCCTCCGGTAG-3') }\end{array}$ & $\begin{array}{l}10 \mu \mathrm{L} \text { FastStart }{ }^{\circledR} \text { PCR } \\
\text { Master Mix; } 900 \mathrm{nM} \\
\text { primer; 200nM probe }\end{array}$ & $\begin{array}{l}95^{\circ} \mathrm{C} 10 \mathrm{~min}, 50 \\
\text { cycles }\left(95^{\circ} \mathrm{C} 15 \mathrm{~s},\right. \\
50^{\circ} \mathrm{C} 1 \mathrm{~min}, 72^{\circ} \mathrm{C} \\
1 \mathrm{~s})\end{array}$ & - & $\begin{array}{l}\text { Francino et al. } \\
(2006)\end{array}$ \\
\hline $\begin{array}{l}\text { SSU-rDNA } \\
\text { Leishmania spp. }\end{array}$ & $\begin{array}{l}\text { LITSR (5'-CTGGATCATTTTCCGATG-3') } \\
\text { L5-8S (5'-TGATACCACTTATCGCACTT-3') }\end{array}$ & $\begin{array}{l}\text { 50mM Tris-HCl; } 10 \mathrm{mM} \\
\mathrm{KCl} ; 1,5 \mathrm{mM} \mathrm{MgCl} 2 \\
\text { 0,2mM DNTP's; } 0,5 \mu \mathrm{M} \\
\text { primer; } 2 U \text { Taq Polimerase }\end{array}$ & $\begin{array}{l}95^{\circ} \mathrm{C} 4 \mathrm{~min}, 35 \\
\text { cycles }\left(95^{\circ} \mathrm{C} 30 \mathrm{~s},\right. \\
53^{\circ} \mathrm{C} 30 \mathrm{~s}, 72^{\circ} \mathrm{C} 1 \\
\min ), 72^{\circ} \mathrm{C} 5 \mathrm{~min}\end{array}$ & Sequencing & $\begin{array}{l}\text { El Tai et al. } \\
(2000)\end{array}$ \\
\hline $\begin{array}{l}\text { Mammalian } \\
\text { ß-actin gene }\end{array}$ & $\begin{array}{l}\text { ß-actin_S (5'-CTGGCACCACACCTTCTA- } \\
\text { CAA-3') } \\
\text { ß-actin_AS (5'-GCCTCGGTCAGCA-3') } \\
\text { Fluoregenic probe (5'-CCACGCG- } \\
\text { CAGCTCG-3') }\end{array}$ & $\begin{array}{l}10 \mu \text { l FastStart }{ }^{\circledR} \text { PCR } \\
\text { Master Mix (Roche); } \\
\text { 300nM primer; 250nM } \\
\text { probe }\end{array}$ & $\begin{array}{l}50^{\circ} \mathrm{C} 2 \mathrm{~min}, 95^{\circ} \mathrm{C} \\
10 \mathrm{~min}, 30 \text { cycles } \\
\left(95^{\circ} \mathrm{C} 15 \mathrm{~s}, 60^{\circ} \mathrm{C}\right. \\
1 \mathrm{~min})\end{array}$ & - & $\begin{array}{l}\text { Manna et al. } \\
(2006)\end{array}$ \\
\hline
\end{tabular}

Amplification for L. infantum was performed in accordance with Francino et al. (2006) (Table 2). Both qPCRs were performed using a LightCycler ${ }^{\circledR} 480$ II thermocycler (Roche). The standard reaction curve was obtained using canine DNA (for the endogenous $\beta$-actin gene) and a DNA sample extracted from $L$. infantum (MCAN/BR/1984/CCC-17.481) in a ten-fold serial dilution (for the L. infantum gene). The DNA concentration was estimated by measuring the absorbance at 260 and $280 \mathrm{~nm}$ in a DS-11 ${ }^{\circledR}$ spectrophotometer (DeNovix). The analyses were performed in accordance with the standards established through MIQE (Minimum Information for Publication of Quantitative real-time PCR Experiments) (BUSTIN et al., 2009). Sterilized ultrapure water was used as a negative control.

\section{$D N A$ sequencing}

After electrophoresis on $1.5 \%$ agarose gel, cPCR products for ITS-1 were removed from the gel and purified using the Illustrated GFX PCR DNA \& Gel Band ${ }^{\circledR}$ purification kit (GE Healthcare), in accordance with the manufacturer's instructions. DNA sequencing was performed using $20 \mathrm{ng} / \mu \mathrm{L}$ of purified PCR product and $5 \mu \mathrm{M}$ of each primer. The samples were sent to the DNA Sequencing Service of the Human Genome and Stem Cell Research Center, at the Biological Institute (IB) of the University of São Paulo (USP). Chromatograms obtained using forward and reverse primers were assembled through the Sequence Scanner 2 software v2.2 and compared using the Clustal W software (available in BioEdit Sequence Alignment Editor, version 7.1.11, Ibis Biosciences,
Carlsbad, CA, USA). The BLAST program (ALTSCHUL et al., 1990) was used to analyze the nucleotide sequences (BLASTN), with the aim of searching for similar genes in international databases (GenBank) and comparing these with the sequences obtained here.

\section{Data analysis}

The chi-square test with a significance level of 5\% was calculated using the $\mathrm{R}$ software, version 3.1.1 (R Development Core Team, 2014) in order to assess the associations between the positivity of dogs classified as without clinical signs, stage I (mild disease), stage II (moderate disease) and stage III (severe disease) in each PCR protocol (13A/13B, MC1/MC2, LITSR/L5.8S and LEISH-1/LEISH-2) for Leishmania spp. detection.

\section{Results}

In this study, all the dogs were ranked in accordance with the disease classification described above. Thus, 22.3\% (48/215) were classified as without clinical signs, 67.5\% (145/215) in stage I (mild disease), $7.0 \%(15 / 215)$ in stage II (moderate disease) and $3.2 \%(7 / 215)$ in stage III (severe disease).

All the DNA samples were positive for the endogenous $\beta$-actin gene. This confirmed the quality of the process of DNA extraction and proved that there were no inhibitors and/or false negative results in the molecular analysis. Regarding DNA extracted from blood samples, tests using primers $13 \mathrm{~A} / 13 \mathrm{~B}$ detected a significantly 
higher number of positive dogs in stage I (25/145) and in total $(42 / 215)$ than did the other tests $(\mathrm{p} \leq 0.05)$. On the other hand, the primers MC1/MC2 detected significantly fewer positive dogs classified as without clinical signs $(0 / 48)$ or in stage I (0/145) and in total $(1 / 215)(\mathrm{p} \leq 0.05)$. Although LITSR/L5.8S showed a higher number of positive animals $(21 / 215)$, there was no significant difference between the results from use of these primers and those from qPCR with LEISH-1/LEISH-2 (15/215), independent of clinical stage $(\mathrm{p}>0.05)$ (Table 3$)$.

Regarding DNA extracted from conjunctival swab samples from the same dogs. The $13 \mathrm{~A} / 13 \mathrm{~B}$ set of primers presented greater detection of positive animals in total $(28 / 215)$ and also of dogs classified as without clinical signs (5/48) or in stage I (16/145), but no significant difference was observed $(p>0.05)$. Like in the blood samples, the MC1/MC2 primers detected a statistically lower number of positive animals $(1 / 215)$ than did the other tests on the swab samples $(\mathrm{p} \leq 0.05)$ (Table 4).

\section{Discussion}

Here, we tested four different molecular tests for detecting Leishmania spp. infection, on 215 dogs that had been classified into four different clinical stages. Our results showed that the primers 13A and 13B (RODGERS et al., 1990) detected a greater number of positive dogs at the onset of the clinical signs of disease (stage I) and in total among the samples, with no significantly greater detection among without clinical signs dogs than was seen among the other primers tested.
The primers 13A/13B, MC-1/MC-2 and LEISH-1/LEISH-2 are sequences that target kinetoplast minicircle DNA (kDNA), while the primers LITSR/L5.8S are designed to target the genomic region of ribosomal (rDNA) and, more specifically, the internal transcribed spacer 1 (ITS-1). In a comparison of six primers for different gene targets, in relation to diagnosing leishmaniases, Koltas et al. (2016) reported that PCR using the kDNA gene target presented good sensitivity and specificity. Their results have also been confirmed by other authors (REALE et al., 1999; LACHAUD et al., 2002; BENSOUSSAN et al., 2006; MOREIRA et al., 2007; ESMAEIL et al., 2011; LOPES et al., 2016).

In our analysis, kDNA-PCR was able to detect positive dogs in all types of samples. This was seen especially when the primers $13 \mathrm{~A} / 13 \mathrm{~B}$ were used. These detected a significantly larger number of positive dogs in blood samples $(\mathrm{p} \leq 0.05)$ and a larger but non-significant number, in conjunctival swabs samples ( $>0.05$ ). In several molecular surveys targeting Leishmania spp. $\mathrm{kDNA}$, the diagnosis was reported to be sensitive (REALE et al., 1999; MIRO et al., 2008; SOLANO-GALLEGO et al., 2011). According to Miró et al. (2008), the sensitivity of PCR protocols can be correlated with the number of copies of the amplified DNA region that are present in the parasite. Each parasite has around 10,000 minicircles with a conserved region of approximately 200 bp and a variable region of 600 bp (MOHAMMADIHA et al., 2013). Specifically, the gene locus of the primers $13 \mathrm{~A} / 13 \mathrm{~B}$ is present in thousands of copies in the cellular genome of the parasite (LIU et al., 2005). Thus, this makes the kDNA the most sensitive target for making the molecular diagnosis of the parasite (MOHAMMADIHA et al., 2013), for both clinically and subclinically

Table 3. Molecular tests for Leishmania spp. detection in blood samples from dogs classified in different clinical stages.

\begin{tabular}{|c|c|c|c|c|}
\hline \multicolumn{5}{|c|}{ Comparison of molecular methods for detection of Leishmania spp. DNA in blood } \\
\hline \multirow{2}{*}{ Clinical Classification } & \multicolumn{3}{|c|}{ Conventional PCR } & \multirow{2}{*}{$\begin{array}{c}\text { Real-Time PCR } \\
\text { LEISH-1/LEISH-2 }\end{array}$} \\
\hline & $13 A / 13 B$ & MC1/MC2 & LITSR/L5-8S & \\
\hline Without clinical signs $(\mathrm{N}=48)$ & $9^{a}$ & $0^{b}$ & $6^{a}$ & $4 \mathrm{ab}$ \\
\hline Stage I $(N=145)$ & $25^{a}$ & $0^{c}$ & $10^{b}$ & $7^{b}$ \\
\hline Stage II $(\mathrm{N}=15)$ & $4^{a}$ & $0^{a}$ & $1^{a}$ & $0^{a}$ \\
\hline Stage III (N= 7) & $4^{\text {a }}$ & $1^{\mathrm{a}}$ & $4^{a}$ & $4^{a}$ \\
\hline Total $(\mathrm{N}=215)$ & $42^{a}$ & $1^{\mathrm{c}}$ & $21^{b}$ & $15^{b}$ \\
\hline
\end{tabular}

Proportion test (chi-square). Different lowercase letters (a, b, c) indicate statistical significance between columns at the 5\% probability level ( $\mathrm{p} \leq 0.05) .13 \mathrm{~A} / 13 \mathrm{~B}: \mathrm{kDNA}$ Leishmania spp.; MC1/MC2: kDNA Leishmania infantum; LITSR/L5-8S: SSU-rDNA Leishmania spp.; LEISH-1/LEISH-2: kDNA Leishmania infantum.

Table 4. Molecular tests for Leishmania spp. detection in conjunctival swab samples from dogs classified in different clinical stages.

\begin{tabular}{|c|c|c|c|c|}
\hline \multicolumn{5}{|c|}{ Comparison of molecular methods for detection of Leishmania spp. DNA in conjunctival swab } \\
\hline \multirow{2}{*}{ Clinical Classification } & \multicolumn{3}{|c|}{ Conventional PCR } & \multirow{2}{*}{$\begin{array}{c}\text { Real-Time PCR } \\
\text { LEISH-1/LEISH-2 }\end{array}$} \\
\hline & $13 A / 13 B$ & MC1/MC2 & LITSR/L5-8S & \\
\hline Without clinical signs $(\mathrm{N}=48)$ & $5^{a}$ & $0^{a}$ & $4^{a}$ & $3^{a}$ \\
\hline Stage I $(N=145)$ & $16^{\mathrm{a}}$ & $0^{\mathrm{b}}$ & $10^{a}$ & $14^{\mathrm{a}}$ \\
\hline Stage II $(\mathrm{N}=09)$ & $4^{a}$ & $0^{\text {a }}$ & $1^{a}$ & $3^{a}$ \\
\hline Stage III $(\mathrm{N}=13)$ & $3^{a}$ & $1^{\text {a }}$ & $2^{a}$ & $4^{a}$ \\
\hline Total $(\mathrm{N}=215)$ & $28^{a}$ & $1^{b}$ & $17^{a}$ & $24^{a}$ \\
\hline
\end{tabular}

Proportion test (chi-square). Different lowercase letters (a, b, c) indicate statistical significance between columns at the $5 \%$ probability level (p s 0.05). 13A/13B: kDNA Leishmania spp.; MC1/MC2: kDNA Leishmania infantum; LITSR/L5-8S: SSU-rDNA Leishmania spp.; LEISH-1/LEISH-2: kDNA Leishmania infantum. 
affected dogs (LACHAUD et al., 2002; MOREIRA et al., 2007). In our study, the primers 13A/13B showed higher sensitivity for detecting Leishmania spp. kDNA from dogs with clinical signs (stages I, II and III) and without clinical signs. However, there was a significant difference $(\mathrm{p} \leq 0.05)$ only in relation to those classified in stage I, thus showing that this technique is useful for detecting the early stages of CVL.

Although also targeting the $\mathrm{kDNA}$, the primers MC-1/MC-2 were less able to detect positive dogs through blood and CS samples, in comparison with $13 \mathrm{~A} / 13 \mathrm{~B}(\mathrm{p}<0.05)$. This may demonstrate that MC-1/MC-2, which is a set of primers that is considered specific for L. infantum $\mathrm{kDNA}$, has lower sensitivity, such that it can only detect animals with higher parasite loads (RAMOS et al., 2012).

In addition, the primers LEISH-1/LEISH-2 are considered efficient for use in qPCR by many authors (FRANCINO et al., 2006; RAMOS et al., 2012; MOHAMMADIHA et al., 2013) and are similar to the primers 13A/13B. However, the TaqMan-MGB probe that was used determines specificity for $L$. infantum DNA (FRANCINO et al., 2006). For this reason, our results showed lower detection of positive dogs through blood samples, compared with what was shown by $13 \mathrm{~A} / 13 \mathrm{~B}(\mathrm{p}<0.05)$. In relation to conjunctival swab samples, these primers sets did not differ statistically. Interestingly, qPCR detected a higher number of positive dogs through CS $(24 / 215)$ than through blood samples $(15 / 215)$. This may have been due to differences in the distribution of the parasites, among tissues and the local immune response (MAIA et al., 2009). In addition, the presence of PCR inhibitors in blood and low parasite loads could explain these results (REALE et al., 1999; LACHAUD et al., 2002).

In fact, conjunctival swabs have been shown to be a sensitive and practical method for collecting samples. This method provides consistent diagnoses through cPCR (LEITE et al., 2010; OLIVEIRA et al., 2015; PEREIRA et al., 2016) and through real-time PCR (SOLANO-GALLEGO et al., 2011; FERREIRA et al., 2014; LEITE et al., 2015; BENASSI et al., 2017), in both symptomatic dogs (STRAUSS-AYALI et al., 2004; FERREIRA et al., 2008; PILATTI et al., 2009) and asymptomatic dogs (LEITE et al., 2010).

Comparison of diagnoses made using specific primers for L. infantum kDNA (MC-1/MC-2 and LEISH-1/LEISH-2) showed that the $\mathrm{MC}$ set presented significant lower detection of positive animals from both the blood and the CS samples. Ramos et al. (2012) also observed the same result using bone marrow, spleen and lymph node tissue to compare the diagnoses with these same primers and protocols. In addition, the MC set detected positive dogs only at the most severe stage of disease (stage III) $(\mathrm{p}<0.05)$. On the other hand, the LEISH set was able to diagnose $L$. infantum $\mathrm{kDNA}$ at all stages (without clinical signs, stages I, II and III). These divergent results may have been due to the lower sensitivity of the primers MC-1/MC-2, such that high parasite loads in blood and tissues would be needed (RAMOS et al., 2012). In turn, qPCR using LEISH-1/LEISH-2 was able to detect parasite DNA even in samples with small amounts of genetic material (RAMOS et al., 2012). Although Mohammadiha et al. (2013) did not find any significant relationship between clinical signs and amounts of Leishmania spp. kDNA in the blood, other authors showed that there was a positive relationship (MANNA et al., 2006; REIS et al., 2006; RODRÍGUEZ-CORTÉS et al., 2010).
Regarding the rDNA target region, the primers LITSR/L5.8S were designed to target the ITS-1 genomic region between the $18 \mathrm{~S}$ rRNA and 5.8S rRNA genes of the parasite (SALLOUM et al., 2016). Our results showed that 21 dogs were cPCR-positive in blood samples and, although this was a notable detection rate, it was lower than the number of dogs that were found to be positive through $\mathrm{cPCR}$ using the $13 \mathrm{~A} / 13 \mathrm{~B}$ set $(\mathrm{p} \leq 0.05)$. Bensoussan et al. (2006) compared of use of ITS-1 PCR with use of PCR on the mini-exon region (ME-PCR) and found that ITS-1 was more sensitive for diagnosing cutaneous leishmaniasis. Subsequently, Koltas et al. (2016) observed that ITS-1 had a better detection rate than that of ME-PCR, but that both of these had lower sensitivity than small subunit rRNA (SSU rRNA). This was supported by other authors, who found that SSU rRNA had better performance in diagnosing leishmaniasis (SCHÖNIAN et al., 2003; ALBUQUERQUE et al., 2017). Schönian et al. (2003) reported that ITS-1 PCR was able to detect 0.2 parasites in samples.

However, the main limitation of use of ITS- 1 is that it detects Leishmania only at the genus level, such that additional tools are needed for species identification (ALBUQUERQUE et al., 2017). In fact, to distinguish between species, the ITS-1 PCR products need to be subjected to sequencing analysis (TENÓRIO et al., 2014; SALLOUM et al., 2016) or to the restriction fragment length polymorphism (RFLP) technique (SCHÖNIAN et al., 2003; SALLOUM et al., 2016). Although the ITS-1 region is a conserved region of DNA, it has several polymorphisms that allow identification of species (ROELFSEMA et al., 2011). Identification at species level is very important in areas in which several Leishmania species are implicated in the leishmaniasis cycle (TSOKANA et al., 2014; ALBUQUERQUE et al., 2017). Thus, several studies have used the L5.8SR/LITSR set to distinguish between Leishmania species (SCHÖNIAN et al., 2003; TENÓRIO et al., 2014; BABUADZE et al., 2016; SALLOUM et al., 2016). ITS-1 PCR is considered to be the next most sensitive discrimination method after RFLP (KOLTAS et al., 2016) or sequencing (SALLOUM et al., 2016). In our study, we used sequencing followed by cPCR, and it was possible to identify some sequences with $99 \%$ or $100 \%$ similarity to L. infantum.

Lastly, it should be remembered that despite the efforts of many research groups, the continuing lack of a gold-standard test for diagnosing of Leishmania spp. infection is a major impediment (RODRÍGUEZ-CORTÉS et al., 2010). Molecular tools such as PCR have improved epidemiological studies on leishmaniasis around the world (GRAMICCIA, 2011) and can help in research on disease control (SCHÖNIAN et al., 2008). We performed four different PCRs to detect Leishmania spp. infection in dogs at several clinical stages and our results showed variation in sensitivity between the primer sets used. The sensitivity of each technique may vary over the course of evolution of the disease and between individuals; therefore, a combination of serological and molecular tests may be necessary to correct the diagnosis (ASSIS et al., 2010; NUNES et al., 2007; QUEIROZ et al., 2010; SILVA et al., 2014). In addition, it has been recommended that the diagnosis of this disease should be based on clinical signs and on the epidemiological characteristics of the region, which may contribute towards correctly identifying truly positive animals (SILVA et al., 2014). 


\section{Conclusion}

Our results emphasize that using associations of more than one technique and/or type of sample are necessary in order to better detect Leishmania spp. infection. Moreover, cPCR using the primers $\mathrm{MC} 1 / \mathrm{MC} 2$ does not readily detect infected dogs; while cPCR using the primers $13 \mathrm{~A} / 13 \mathrm{~B}$ is better for detecting Leishmania spp. infection in blood, mainly at the onset of dog's disease.

\section{Acknowledgements}

We would like to thank the animal protection organizations of Pirassununga, Santa Cruz das Palmeiras, Ilha Solteira and Andradina. This study was financed in part by Foundation for Research Support of the State of São Paulo (FAPESP; grant number 2016/03774-5) and the Coordenação de Aperfeiçoamento de Pessoal de Nível Superior - Brasil (CAPES) - Finance Code 001.

\section{References}

Albuquerque A, Campino L, Cardoso L, Cortes S. Evaluation of four molecular methods to detect Leishmania infection in dogs. Parasit Vectors 2017; 10(1): 57. http://dx.doi.org/10.1186/s13071-017-2002-2. PMid:28285595.

Altschul SF, Gish W, Miller W, Myers EW, Lipman DJ. Basic local alignment search tool. J Mol Biol 1990; 215(3): 403-410. http://dx.doi. org/10.1016/S0022-2836(05)80360-2. PMid:2231712.

Alvar J, Vélez ID, Bern C, Herrero M, Desjeux P, Cano J, et al. Leishmaniasis worldwide and global estimates of its incidence. PLoS One 2012; 7(5): e35671. http://dx.doi.org/10.1371/journal.pone.0035671. PMid:22693548.

Arias J, Beltrán F, Desjeux P, Walton B. Epidemiología y control de la leishmaniasis en las Américas, por país o territorio. Washington: Organização Panamericana de Saúde; 1996. (Cuardeno Técnico; vol. 44).

Ashford RW. Leishmaniasis reservoirs and their significance in control. Clin Dermatol 1996; 14(5): 523-532. http://dx.doi.org/10.1016/0738081X(96)00041-7. PMid:8889331.

Assis J, Queiroz NMGP, Silveira RCV, Nunes CM, Oliveira TMFS, Noronha ACF Jr, et al. Estudo comparativo dos métodos diagnósticos para Leishmaniose Visceral em cães oriundos de Ilha Solteira, SP. Rev Bras Parasitol Vet 2010; 19(1): 17-25. http://dx.doi.org/10.1590/S198429612010000100005 . PMid:20385055.

Babuadze G, Farlow J, Koning HP, Carrillo E, Chakhunashvili G, Murskvaladze M, et al. Seroepidemiology and molecular diversity of Leishmania donovani complex in Georgia. Parasit Vectors 2016; 9(1): 279. http://dx.doi.org/10.1186/s13071-016-1558-6. PMid:27177688.

Benassi JC, Benvenga GU, Ferreira HL, Pereira VF, Keid LB, Soares $\mathrm{R}$, et al. Detection of Leishmania infantum DNA in conjunctival swabs of cats by quantitative real-time PCR. Exp Parasitol 2017; 177: 93-97. http://dx.doi.org/10.1016/j.exppara.2017.04.004. PMid:28438522.

Bensoussan E, Nasereddin A, Jonas F, Schnur LF, Jaffe CL. Comparison of PCR assays for diagnosis of cutaneous leishmaniasis. J Clin Microbiol 2006; 44(4): 1435-1439. http://dx.doi.org/10.1128/JCM.44.4.14351439.2006. PMid:16597873.
Brasil. Ministério da Saúde. Nota técnica conjunta no 01/2001-CGDT/ DEVIT/SUS/MS: esclarecimento sobre a substituição do protocolo diagnóstico da leishmaniose visceral canina (LVC) [online]. Brasília; 2011 [cited 2018 Aug 20]. Available from: http://www.sgc.goias.gov.br/upload/ arquivos/2012-05/nota-tecnica-no.-1-2011_cglab_cgdt1_lvc.pdf

Brasil. Ministério da Saúde. Casos de Leishmaniose Tegumentar Brasil: grandes regióes e unidades federadas 1990 a 2016 [online]. Brasília; 2018a [cited 2018 June 5]. Available from: http://portalarquivos.saude.gov.br/ images/pdf/2017/setembro/14/LT-Casos.pdf

Brasil. Ministério da Saúde. Casos confirmados de Leishmaniose Visceral, Brasil: grandes regiöes e unidades federadas 1990 a 2016 [online]. Brasília; 2018b [cited 2018 June 5]. Available from: http://portalarquivos.saude. gov.br/images/pdf/2016/maio/20/LV-Casos.pdf

Brasil. Ministério da Saúde. Leishmaniose Tegumentar Americana: casos confirmados notificados no sistema de informação de agravos de notificação, 2001 a 2006, São Paulo [online]. Brasília; 2018c [cited 2018 June 5]. Available from: http://tabnet.datasus.gov.br/cgi/deftohtm.exe?sinanwin/ cnv/ltasp.def

Brasil. Ministério da Saúde. Leishmaniose Tegumentar Americana: casos confirmados notificados no sistema de informaçāo de agravos de notificação, 2007 a 2017, São Paulo [online]. Brasília; 2018d [cited 2018 June 5]. Available from: http://tabnet.datasus.gov.br/cgi/deftohtm.exe?sinannet/ cnv/ltasp.def

Brasil. Ministério da Saúde. Leishmaniose Visceral: casos confirmados notificados no sistema de informação de agravos de notificação, 2001 a 2006, São Paulo [online]. Brasília; 2018e [cited 2018 July 8]. Available from: http://tabnet.datasus.gov.br/cgi/deftohtm.exe?sinanwin/cnv/leishvsp.def

Brasil. Ministério da Saúde. Leishmaniose Visceral: casos confirmados notificados no sistema de informação de agravos de notificação, 2007 a 2017, São Paulo [online]. Brasília; 2018 [cited 2018 July 8]. Available from: http://tabnet.datasus.gov.br/cgi/deftohtm.exe?sinannet/cnv/leishvsp.def

Bustin SA, Benes V, Garson JA, Hellemans J, Huggett J, Kubista M, et al. The MIQE guidelines: minimum information for publication of quantitative real-time PCR experiments. Clin Chem 2009; 55(4): 611-622. http:// dx.doi.org/10.1373/clinchem.2008.112797. PMid:19246619.

Cortes S, Rolão N, Ramada J, Campino L. PCR as a rapid and sensitive tool in the diagnosis of human and canine leishmaniasis using Leishmania donovani sl-specific kinetoplastid primers. Trans $\mathrm{R}$ Soc Trop Med Hyg 2004; 98(1): 12-17. http://dx.doi.org/10.1016/S0035-9203(03)000026. PMid:14702834.

Coura-Vital W, Marques MJ, Veloso VM, Roatt BM, Aguiar-Soares RDO, Reis LES, et al. Prevalence and factors associated with Leishmania infantum infection of dogs from an urban area of Brazil as identified by molecular methods. PLoS Negl Trop Dis 2011; 5(8): e1291. http://dx.doi. org/10.1371/journal.pntd.0001291. PMid:21858243.

Courtenay O, Quinnell RJ, Garcez LM, Shaw JJ, Dye C. Infectiousness in a cohort of brazilian dogs: why culling fails to control visceral leishmaniasis in areas of high transmission. J Infect Dis 2002; 186(9): 1314-1320. http://dx.doi.org/10.1086/344312. PMid:12402201.

Degrave W, Fernandes O, Campbell D, Bozza M, Lopes U. Use of molecular probes and PCR for detection and typing of Leishmania - a mini-review. Mem Inst Oswaldo Cruz 1994; 89(3): 463-469. http://dx.doi. org/10.1590/S0074-02761994000300032. PMid:7476234.

Desjeux P. Leishmaniasis: current situation and new perspectives. Comp Immunol Microbiol Infect Dis 2004; 27(5): 305-318. http://dx.doi. org/10.1016/j.cimid.2004.03.004. PMid:15225981. 
Duarte IRM, Arruda CCP, Andrade ARO, Nunes VLB, Souza AI, Dourado DM, et al. Comportamento biológico de Leishmania (L.) amazonensis isolada de um gato doméstico (Felis catus) de mato Grosso do Sul, Brasil. Rev Patol Trop 2010; 39(1): 33-40.

El Tai N, Osman O, El Fari M, Presber W, Schönian G. Genetic heterogeneity of ribosomal internal transcribed spacer in clinical samples of Leishmania donovani spotted on filter paper as revealed by single-strand conformation polymorphisms and sequencing. Trans R Soc Trop Med Hyg 2000; 94(5): 575-579. http://dx.doi.org/10.1016/S0035-9203(00)900932. PMid:11132393.

Esmaeil F, Mohammad F, Majid K. Molecular and seroepidemiological study of Leishmania infantum infection among humans, dogs and wild canines from Azarshahr (new endemic focus), Iran. Afr J Microbiol Res 2011; 5(10): 1237-1242. http://dx.doi.org/10.5897/AJMR11.058.

Ferreira ALC, Carregal VM, Ferreira SA, Leite RS, Andrade ASR. Detection of Leishmania infantum in 4 different dog samples by real-time PCR and ITS-1 nested PCR. Diagn Microbiol Infect Dis 2014; 78(4): 418-421. http://dx.doi.org/10.1016/j.diagmicrobio.2013.10.015. PMid:24485588.

Ferreira SA, Ituassu LT, Melo MN, Andrade ASR. Evaluation of the conjunctival swab for canine visceral leishmaniasis diagnosis by PCRhybridization in Minas Gerais State, Brazil. Vet Parasitol 2008; 152(3-4): 257-263. http://dx.doi.org/10.1016/j.vetpar.2007.12.022. PMid:18242866.

Francino O, Altet L, Sánchez-Robert E, Rodriguez A, Solano-Gallego L, Alberola J, et al. Advantages of real-time PCR assay for diagnosis and monitoring of canine leishmaniosis. Vet Parasitol 2006; 137(3-4): 214221. http://dx.doi.org/10.1016/j.vetpar.2006.01.011. PMid:16473467.

Gramiccia M. Recent advances in leishmaniosis in pet animals: epidemiology, diagnostics and anti-vectorial prophylaxis. Vet Parasitol 2011; 181(1): 2330. http://dx.doi.org/10.1016/j.vetpar.2011.04.019. PMid:21570192.

Grimaldi G Jr, Teva A, Ferreira AL, Santos CB, Pinto IS, Azevedo CT, et al. Evaluation of a novel chromatographic immunoassay based on Dual-Path Platform technology (DPPR ${ }^{\circledR} \mathrm{CVL}$ rapid test) for the serodiagnosis of canine visceral leishmaniasis. Trans R Soc Trop Med Hyg 2012; 106(1): 54-59. http://dx.doi.org/10.1016/j.trstmh.2011.10.001. PMid:22137538.

John SWM, Weitzner G, Rozen R, Scriver CR. A rapid procedure for extracting genomic DNA from leukocytes. Nucleic Acids Res 1991; 19(2): 408. http://dx.doi.org/10.1093/nar/19.2.408. PMid:2014181.

Koltas IS, Eroglu F, Uzun S, Alabaz D. A comparative analysis of different molecular targets using PCR for diagnosis of old world leishmaniasis. Exp Parasitol2016; 164: 43-48. http://dx.doi.org/10.1016/j.exppara.2016.02.007. PMid:26896641.

Lachaud L, Chabbert E, Dubessay P, Dereure J, Lamothe J, Dedet JP, et al. Value of two PCR methods for the diagnosis of canine visceral leishmaniasis and the detection of asymptomatic carriers. Parasitology 2002; 125(3): 197-207. http://dx.doi.org/10.1017/S0031182002002081. PMid:12358417.

Lahiri DK, Numberger JI Jr. A rapid non-enzymatic method for the preparation of HMW DNA from blood for RFLP studies. Nucleic Acids Res 1991; 19(19): 5444. http://dx.doi.org/10.1093/nar/19.19.5444. PMid:1681511.

Langoni H, Richini-Pereira VB, Scremin C, Troncarelli MZ, Camargo JB, Machado JG, et al. Detecção molecular de Leishmania spp. em material de hemocultura, e diagnóstico sorológico para leishmaniose em cães procedentes do bairro da Conquista, São Manuel-SP, Brasil. Vet Zootec 2015; 22(4): 580-590.
Leite RS, Ferreira SA, Ituassu LT, Melo MN, Andrade ASR. PCR diagnosis of visceral leishmaniasis in asymptomatic dogs using conjunctival swab samples. Vet Parasitol 2010; 170(3-4): 201-206. http://dx.doi.org/10.1016/j. vetpar.2010.02.020. PMid:20227834.

Leite RS, Souza NA, Barbosa AD, Ferreira ALC, Andrade ASR. Evaluation of conjunctival swab as a mass-screening tool for molecular diagnosis of canine visceral leishmaniasis. Parasitol Res 2015; 114(6): 2255-2262. http://dx.doi.org/10.1007/s00436-015-4418-y. PMid:25782681.

Liu B, Liu Y, Motyka SA, Agbo EE, Englund PT. Fellowship of the rings: the replication of kinetoplast DNA. Trends Parasitol 2005; 21(8): 363-369. http://dx.doi.org/10.1016/j.pt.2005.06.008. PMid:15967722.

Lopes EG, Geraldo CA Jr, Marcili A, Silva RD, Keid LB, Oliveira TMFS, et al. Performance of conventional PCRs based on primers directed to nuclear and mitochondrial genes for the detection and identification of Leishmania spp. Rev Inst Med Trop São Paulo 2016; 58: 41. http://dx.doi. org/10.1590/S1678-9946201658041. PMid:27253743.

Maia C, Campino L. Can domestic cats be considered reservoir hosts of zoonotic leishmaniasis? Trends Parasitol 2011; 27(8): 341-344. http:// dx.doi.org/10.1016/j.pt.2011.03.008. PMid:21570915.

Maia C, Campino L. Methods for diagnosis of canine leishmaniasis and immune response to infection. Vet Parasitol 2008; 158(4): 274-287. http:// dx.doi.org/10.1016/j.vetpar.2008.07.028. PMid:18789583.

Maia C, Ramada J, Cristóvão J, Gonçalves L, Campino L. Diagnosis of canine leishmaniasis: conventional and molecular techniques using different tissues. Vet J2009; 179(1): 142-144. http://dx.doi.org/10.1016/j. tvjl.2007.08.009. PMid:17936654.

Manna L, Reale S, Viola E, Vitale F, Manzillo VF, Michele PL, et al. Leishmania DNA load and cytokine expression levels in asymptomatic naturally infected dogs. Vet Parasitol 2006; 142(3-4): 271-280. http:// dx.doi.org/10.1016/j.vetpar.2006.06.028. PMid:16920264.

Miro G, Cardoso L, Pennisi MG, Oliva G, Baneth G. Canine leishmaniosis - new concepts and insights on an expanding zoonosis: part two. Trends Parasitol2008; 24(8): 371-377. http://dx.doi.org/10.1016/j.pt.2008.05.003. PMid:18603476.

Mohammadiha A, Mohebali M, Haghighi A, Mahdian R, Abadi AR, Zarei $Z$, et al. Comparison of real-time PCR and conventional PCR with two DNA targets for detection of Leishmania (Leishmania) infantum infection in human and dog blood samples. Exp Parasitol 2013; 133(1): 89-94. http://dx.doi.org/10.1016/j.exppara.2012.10.017. PMid:23159412.

Moreira M, Luvizotto MCR, Garcia JF, Corbett C, Laurenti M. Comparison of parasitological, immunological and molecular methods for the diagnosis of leishmaniasis in dogs with different clinical signs. Vet Parasitol 2007; 145(3-4): 245-252. http://dx.doi.org/10.1016/j. vetpar.2006.12.012. PMid:17257764.

Nunes CM, Dias AKK, Gottardi FP, Paula HB, Azevedo MAA, Lima VMF, et al. Polymerase chain reaction evaluation for canine visceral leishmaniasis diagnosis in dog blood samples. Rev Bras Parasitol Vet 2007; 16(1): 5-9. PMid:17588315.

Oliveira TMFS, Furuta PI, Carvalho D, Machado RZ. A study of cross-reactivity in serum samples from dogs positive for Leishmania spp., Babesia canis and Ehrlichia canis in enzyme-linked immunosorbent assay and indirect fluorescent antibody test. Rev Bras Parasitol Vet 2008; 17(1): 7-11. http://dx.doi.org/10.1590/S1984-29612008000100002. PMid:18554433.

Oliveira TMFS, Pereira VF, Benvenga GU, Martin MFA, Benassi JC, Silva DT, et al. Conjunctival swab PCR to detect Leishmania spp. in cats. 
Rev Bras Parasitol Vet 2015; 24(2): 220-222. http://dx.doi.org/10.1590/ S1984-29612015016. PMid:26154963.

Pereira VF, Benassi JC, Starke-Buzetti WA, Silva DT, Ferreira HL, Keid LB, et al. Detection of canine visceral leishmaniasis by conjunctival swab PCR. Rev Soc Bras Med Trop 2016; 49(1): 104-106. http://dx.doi. org/10.1590/0037-8682-0191-2015. PMid:27163572.

Pilatti MM, Ferreira AF, Melo MM, Andrade ASR. Comparison of PCR methods for diagnosis of canine visceral leishmaniasis in conjunctival swab samples. Res Vet Sci 2009; 87(2): 255-257. http://dx.doi.org/10.1016/j. rvsc.2009.02.005. PMid:19298988.

Queiroz NMGP, Assis J, Oliveira TMFS, Machado RZ, Nunes CM, Starke-Buzetti WA. Canine Visceral Leishmaniasis diagnosis by immunohistochemistry and PCR in skin tissues in association with RIFI and ELISA-test. Rev Bras Parasitol Vet 2010; 19(1): 32-38. http://dx.doi. org/10.1590/S1984-29612010000100007. PMid:20385057.

Quinnell R, Courtenay O. Transmission, reservoir hosts and control of zoonotic visceral leishmaniasis. Parasitology 2009; 136(14): 1915-1934. http://dx.doi.org/10.1017/S0031182009991156. PMid:19835643.

R Development Core Team. $R$ : a language and enviroment for statistical computing [online]. Vienna: R Foundation for Statistical Computing; 2014 [cited 2018 Feb 15]. Available from: http://www.Rproject.org/

Ramos RAN, Ramos CAN, Jusi MMG, Araújo FR, Machado RZ, Faustino $\mathrm{MAG}$, et al. Polymerase chain reaction and real-time PCR for diagnosing of Leishmania infantum chagasi in dogs. Rev Bras Parasitol Vet 2012; 21(3): 192-195. http://dx.doi.org/10.1590/S1984-29612012000300003. PMid:23070425.

Reale S, Maxia L, Vitale F, Glorioso N, Caracappa S, Vesco G. Detection of Leishmania infantum in dogs by PCR with lymph node aspirates and blood. J Clin Microbiol 1999; 37(9): 2931-2935. PMid:10449478.

Reis AB, Martins-Filho OA, Carvalho AT, Carvalho MG, Mayrink W, Silva JCF, et al. Parasite density and impaired biochemical/hematological status are associated with severe clinical aspects of canine visceral leishmaniasis. Res Vet Sci 2006; 81(1): 68-75. http://dx.doi.org/10.1016/j. rvsc.2005.09.011. PMid:16288789.

Rodgers MR, Popper SJ, Wirth DF. Amplification of kinetoplast DNA as a tool in the detection and diagnosis of Leishmania. Exp Parasitol 1990; 71(3): 267-275. http://dx.doi.org/10.1016/0014-4894(90)90031-7. PMid:2170165.

Rodríguez-Cortés A, López-Fuertes L, Timón M, Alberola J, Ojeda A, Francino O. Leishmania infection: Laboratory diagnosing in the absence of a "gold standard". Am J Trop Med Hyg 2010; 82(2): 251-256. http:// dx.doi.org/10.4269/ajtmh.2010.09-0366. PMid:20134001.

Roelfsema JH, Nozari N, Herremans T, Kortbeek LM, Pinelli E. Evaluation and improvement of two PCR targets in molecular typing of clinical samples of Leishmania patients. Exp Parasitol 2011; 127(1):36-41. http:// dx.doi.org/10.1016/j.exppara.2010.06.024. PMid:20599989.
Salloum T, Khalifeh I, Tokajian S. Detection, molecular typing and phylogenetic analysis of Leishmania isolated from cases of leishmaniasis among Syrian refugees in Lebanon. Parasite Epidemiol Control 2016; 1(2): 159-168. http://dx.doi.org/10.1016/j.parepi.2016.02.002. PMid:29988171.

Schönian G, Mauricio I, Gramiccia M, Cañavate C, Boelaert M, Dujardin JC. Leishmaniases in the Mediterranean in the era of molecular epidemiology. Trends Parasitol 2008; 24(3): 135-142. http://dx.doi. org/10.1016/j.pt.2007.12.006. PMid:18262469.

Schönian G, Nasereddin A, Dinse N, Schweynoch C, Schallig HD, Presber W, et al. PCR diagnosis and characterization of Leishmania in local and imported clinical samples. Diagn Microbiol Infect Dis 2003 47(1): 349-358. http://dx.doi.org/10.1016/S0732-8893(03)00093-2. PMid:12967749.

Silva DT, Starke-Buzetti WA, Alves-Martin MF, Paixão MS, Tenório MS, Lopes MLM. Comparative evaluation of several methods for Canine Visceral Leishmaniasis diagnosis. Rev Bras Parasitol Vet 2014; 23(2): 179 186. http://dx.doi.org/10.1590/S1984-29612014033. PMid:25054496.

Soares IR, Silva SO, Moreira FM, Prado LG, Fantini P, Maranhão RP, et al. First evidence of autochthonous cases of Leishmania (Leishmania) infantum in horse (Equus caballus) in the Americas and mixed infection of Leishmania infantum and Leishmania (Viannia) braziliensis. Vet Parasitol 2013; 197(3-4): 665-669. http://dx.doi.org/10.1016/j.vetpar.2013.06.014. PMid:23845306.

Solano-Gallego L, Miró G, Koutinas A, Cardoso L, Pennisi MG, Ferrer $\mathrm{L}$, et al. LeishVet guidelines for the practical management of canine leishmaniosis. Parasit Vectors 2011; 4(1): 86. http://dx.doi.org/10.1186/17563305-4-86. PMid:21599936.

Strauss-Ayali D, Jaffe CL, Burshtain O, Gonen L, Baneth G. Polymerase chain reaction using noninvasively obtained samples, for the detection of Leishmania infantum DNA in dogs. J Infect Dis 2004; 189(9): 17291833. http://dx.doi.org/10.1086/383281. PMid:15116312.

Tenório MS, Sousa LO, Alves-Martin MF, Paixão MS, Rodrigues MV, Starke-Buzetti WA, et al. Molecular identification of trypanosomatids in wild animals. Vet Parasitol 2014; 203(1-2): 203-206. http://dx.doi. org/10.1016/j.vetpar.2014.02.010. PMid:24636787.

Troncarelli MZ, Camargo JB, Machado JG, Lucheis SB, Langoni H. Leishmania spp. and/or Trypanosoma cruzi diagnosis in dogs from endemic and nonendemic areas for canine visceral leishmaniasis. Vet Parasitol 2009; 164(2-4): 118-123. http://dx.doi.org/10.1016/j.vetpar.2009.06.027. PMid:19625128.

Tsokana CN, Athanasiou LV, Valiakos G, Spyrou V, Manolakou K, Billinis C. Molecular diagnosis of leishmaniasis, species identification and phylogenetic analysis. In: Claborn DM, editor. Leishmaniasis: trends in epidemiology, diagnosis and treatment. Missouri: InTechOpen; 2014.

World Health Organization WHO. Leishmaniasis in high-burden countries: an epidemiological update based on data reported in 2014 Wkly Epidemiol Rec 2016; 91(22): 286-296. PMid:27263128. 